\title{
Protein Synthesis during Germination and Appressorium Formation of Colletotrichum lagenarium Spores
}

\author{
By K. SUZUKI,* I. FURUSAWA, N. ISHIDA AND M. YAMAMOTO \\ Laboratory of Plant Pathology, Faculty of Agriculture, Kyoto University, Kyoto 606, Japan
}

(Received 7 August 1980; revised 6 October 1980)

\begin{abstract}
Protein synthesis during germination and appressorium formation of Colletotrichum lagenarium spores was investigated by sodium dodecyl sulphate-polyacrylamide gel electrophoresis and fluorography. Synthesis of polypeptides with molecular masses of 72,43 and 38 kilodaltons was detected only in the $20000 \mathrm{~g}$ supernatant fraction of spore homogenates at early stages $(5-25 \mathrm{~min})$ of incubation. These polypeptides are probably associated with the protein synthesis essential for spore germination that occurs within $40 \mathrm{~min}$ from the start of incubation. A polypeptide with a molecular mass of 95 kilodaltons was specifically synthesized only when appressoria were formed. When synthesis of proteins, including the 95 kilodalton polypeptide, was completely inhibited by cycloheximide added after $1 \mathrm{~h}$ incubation, appressoria matured in structure but not in function; they seemed to have no ability to penetrate artificial membranes.
\end{abstract}

\section{INTRODUCTION}

It is generally accepted that protein synthesis is essential for fungal spore germination (Lovett, 1976). Qualitative and quantitative differences in proteins synthesized at the early and later stages of spore germination have been reported for Blastocladiella emersonii (Silverman et al., 1974) and Botryodiplodia theobromae (Van Etten et al., 1972; Wenzler \& Brambl, 1978), but the proteins synthesized during spore germination have not been identified and their function has not been sufficiently discussed.

In some plant pathogenic fungi, the formation of appressoria is a prerequisite of invasion of host plants (Emmett \& Parbery, 1975). A relation between formation of infection structures and protein synthesis has been reported for a few plant pathogenic fungi (Staples \& Yaniv, 1976) and the formation of infection structures in rust uredospores was blocked by inhibitors of protein and RNA synthesis (Dunkle et al., 1969; Ramakrishnan \& Staples, 1970). Protein synthesis was also required for appressorium formation by anthracnose fungi such as Colletotrichum trifolii (Miehle \& Lukezic, 1972) and C. truncatum (Staples et al., 1976).

Spores of Colletotrichum lagenarium can germinate even if protein synthesis is inhibited by cycloheximide from 40 min after the start of incubation, but before this time protein synthesis is indispensable for spore germination (Furusawa et al., 1977). Appressorium formation of this fungus is temperature-sensitive: appressoria formed when spores were incubated at $24{ }^{\circ} \mathrm{C}$, but did not form at $32{ }^{\circ} \mathrm{C}$ (Ishida \& Akai, 1969). Moreover, appressorium formation could also be influenced by antibiotics (Tani et al., 1977).

In the work reported here, proteins synthesized during spore germination and appressorium formation of $C$. lagenarium were analysed by sodium dodecyl sulphatepolyacrylamide gel electrophoresis; the function of these proteins in the morphological differentiation of spores is discussed. 


\section{METHODS}

Spores. Colletotrichum lagenarium (Pass.) Ellis and Halsted was cultured on potato sucrose agar medium at $24{ }^{\circ} \mathrm{C}$ for $7 \mathrm{~d}$. Spores on the mycelial mat were collected with a brush and washed three times by centrifugation with ice-cold distilled water (Tani et al., 1977).

Preparation of crude protein for electrophoresis. To investigate qualitative changes of proteins synthesized in $C$. lagenarium spores, $5 \mathrm{ml}$ of spore suspension $\left(5 \times 10^{5}\right.$ spores $\left.\mathrm{ml}^{-1}\right)$ containing $0.3 \mathrm{mM}$-chloramphenicol and $0.01 \%(\mathrm{v} / \mathrm{v})$ Tween 20 was poured into a Petri dish $(9 \mathrm{~cm}$ diam. $)$ and the spores were pulse labelled with ${ }^{3} \mathrm{H}$ |leucine $\left[5 \mu \mathrm{Ci} \mathrm{ml}^{-1}\right.$, specific activity $53 \mathrm{mCi} \mathrm{mmol}^{-1}\left(1.96 \mathrm{GBq} \mathrm{mmol}^{-1}\right)$; The Radiochemical Center, Japan] for 20-30 min. The Petri dish was then placed on ice and $1 \mathrm{ml} 355 \mu \mathrm{M}$-cycloheximide was added to the spore suspension to suppress further protein synthesis completely. The spores were collected by centrifugation at $1500 \mathrm{~g}$ for $10 \mathrm{~min}$ and homogenized in a Potter glass homogenizer with $100-150 \mu \mathrm{l} 0 \cdot 1 \mathrm{M}$-Tris/ $\mathrm{HCl}$ buffer, $\mathrm{pH} 8.0$, containing $0.01 \mathrm{M}-\mathrm{Na}_{2}$ EDTA and $0.01 \%(\mathrm{v} / \mathrm{v}) 2$-mercaptoethanol. The homogenate was centrifuged at $500 \mathrm{~g}$ for $1 \mathrm{~min}$ to remove undisrupted spores. To the supernatant was added an equal volume of $0.0625 \mathrm{M}-\mathrm{Tris} / \mathrm{HCl}$ buffer, pH 6.8, containing $2 \%(\mathrm{w} / \mathrm{v})$ sodium dodecyl sulphate (SDS), $2 \%(\mathrm{v} / \mathrm{v}) 2$-mercaptoethanol, $10 \%(\mathrm{v} / \mathrm{v})$ glycerol and $0.01 \%(\mathrm{w} / \mathrm{v})$ bromophenol blue (Laemmli, 1970). The mixture was boiled for 3-5 min, then centrifuged at $3000 \mathrm{~g}$ for $20 \mathrm{~min}$ and the resulting supernatant was subjected to SDS-polyacrylamide gel electrophoresis (SDS-PAGE) on $10 \%(\mathrm{w} / \mathrm{v})$ gels. To count radioactivity, $20 \mu \mathrm{l}$ of each sample was placed on a Whatman $3 \mathrm{MM}$ filter paper $(24 \mathrm{~mm}$ diam.). Each filter paper was washed three times with $30 \mathrm{ml} 5 \%(\mathrm{w} / \mathrm{v})$ cold trichloroacetic acid (TCA) for $15 \mathrm{~min}$ and then washed three times with ethanol. The radioactivity was counted in a liquid scintillation spectrometer (Packard, model 2425) as described previously (Furusawa et al., 1977).

Electrophoresis and fluorography. Polyacrylamide gels were prepared according to Studier (1973). Samples of $20-60 \mu \mathrm{l}$ were loaded on to $4 \cdot 5 \%(\mathrm{w} / \mathrm{v})$ acrylamide gel (about $1 \mathrm{~cm}$ depth) stacked on $10 \%$ acrylamide gel $(10 \times$ $15 \mathrm{~cm}, 2 \mathrm{~mm}$ thick). Electrophoresis was carried out using the buffer system of Laemmli (1970) at $40 \mathrm{~V} \mathrm{for} 16 \mathrm{~h}$ at room temperature. In order to estimate the molecular masses of the synthesized polypeptides, human gamma globulin (mol. mass 160000 daltons), rinderserum albumin (68000), ovalbumin (45000) and myoglobin (17800) (all from Mann Research Laboratories) were co-electrophoresed. After electrophoresis, the gel was treated with $50 \%$ TCA for $4 \mathrm{~h}$ at $4{ }^{\circ} \mathrm{C}$ and stained with $0.1 \%(\mathrm{w} / \mathrm{v})$ Coomassie brilliant blue at $35{ }^{\circ} \mathrm{C}$ for $1 \mathrm{~h}$ and then destained in a solution of $30 \%(\mathrm{v} / \mathrm{v})$ methanol $/ 10 \%(\mathrm{v} / \mathrm{v})$ acetic acid. The gel was processed for fluorography (Bonner \& Laskey, 1974) and then dried under vacuum at $65^{\circ} \mathrm{C}$ for $1 \mathrm{~h}$ on Whatman $3 \mathrm{MM}$ paper. Kodak X-O-Mat X-ray film pre-exposed to a brief flash of light (Laskey \& Mills, 1975) was placed in contact with the dried gel, exposed at $-70^{\circ} \mathrm{C}$ for $10-14 \mathrm{~d}$, and developed.

Observation of the penetration process on cellulose membranes. A nitrocellulose membrane $(2 \times 2 \mathrm{~cm})$, prepared from Visking cellulose tubing, with a uniform coating of spores was soaked in $2 \mathrm{ml}$ sterile distilled water in a Petri dish $(4.5 \mathrm{~cm}$ diam.). After $1 \mathrm{~h}$ incubation, the water was exchanged for $2 \mathrm{ml}$ cycloheximide solution $(3.55 \mu \mathrm{M})$. After various incubation times, the membrane was washed with sterile water, replaced in distilled water, and incubated for a further $48 \mathrm{~h}$. The membrane was stained with lactophenol cotton blue or $\mathrm{ZnCl}_{2} / \mathrm{KI}$ solution (Araki \& Miyagi, 1976). After washing with water, penetration hyphae originating from appressoria and halo zones around the penetration sites were observed by light microscopy.

\section{RES ULT S}

Colletotrichum lagenarium spores began to germinate within $3 \mathrm{~h}$ at $24^{\circ} \mathrm{C}$. The tip of the germ tube began to swell within $5 \mathrm{~h}$ at this temperature, and pigmented appressoria were formed by $8 \mathrm{~h}$; at $32{ }^{\circ} \mathrm{C}$, the germ tube elongated continuously without forming appressoria (Tani et al., 1977). Germinating spores were pulse-labelled with $\left[{ }^{3} \mathrm{H}\right]$ leucine $\left(5 \mu \mathrm{Ci} \mathrm{ml}{ }^{-1}\right)$ at $24^{\circ} \mathrm{C}$ for a $20 \mathrm{~min}$ period: $5-25 \mathrm{~min}, 60-80 \mathrm{~min}$ or $160-180 \mathrm{~min}$ after the start of incubation. Many polypeptides with different molecular masses were detected on the fluorograms for each of the pulse periods (Fig. 1 $a$ ). Polypeptides with molecular masses of $155,93,76,72,60,43$ and 38 kilodaltons $(\mathrm{K})$ were synthesized specifically in the 5-25 min pulse period, whereas $210 \mathrm{~K}$ and $90 \mathrm{~K}$ polypeptides were only detected in the $160-180 \mathrm{~min}$ pulse period. Many of the polypeptides detected were common to the 5-25 and 60-80 min pulse periods and some were common to all three pulse periods.

To investigate the distribution of polypeptides synthesized during the three pulse periods, the crude protein fractions were separated by centrifugation into $1000 \mathrm{~g}$ pellet, $20000 \mathrm{~g}$ pellet and $20000 \mathrm{~g}$ supernatant fractions. The $20000 \mathrm{~g}$ pellet fraction contained $5-7 \%$ of the total radioactivity incorporated into acid-insoluble material. The $1000 \mathrm{~g}$ pellet and $20000 \mathrm{~g}$ supernatant fractions contained $44-60 \%$ and $35-50 \%$ of the total radioactivity, respectively. 


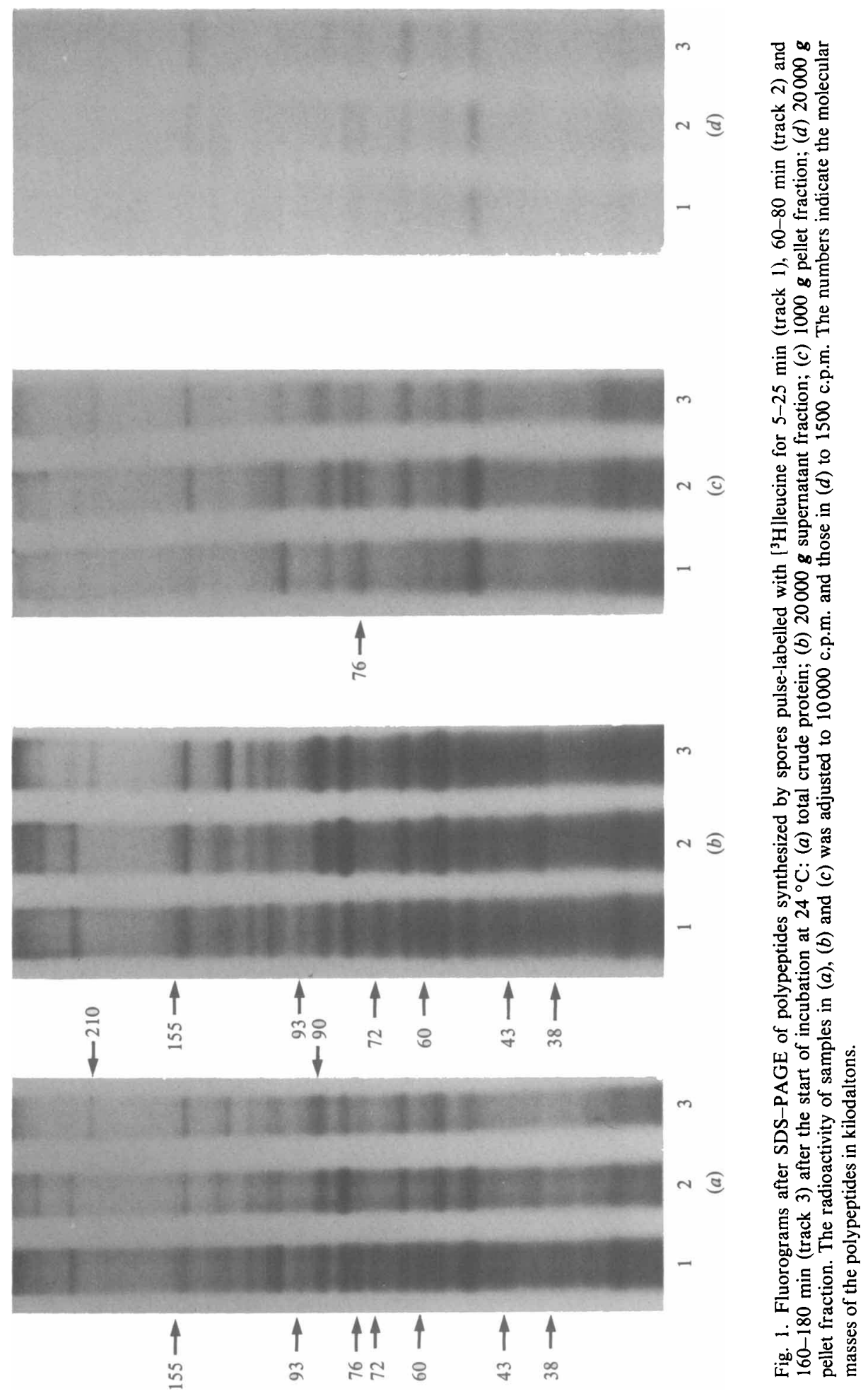



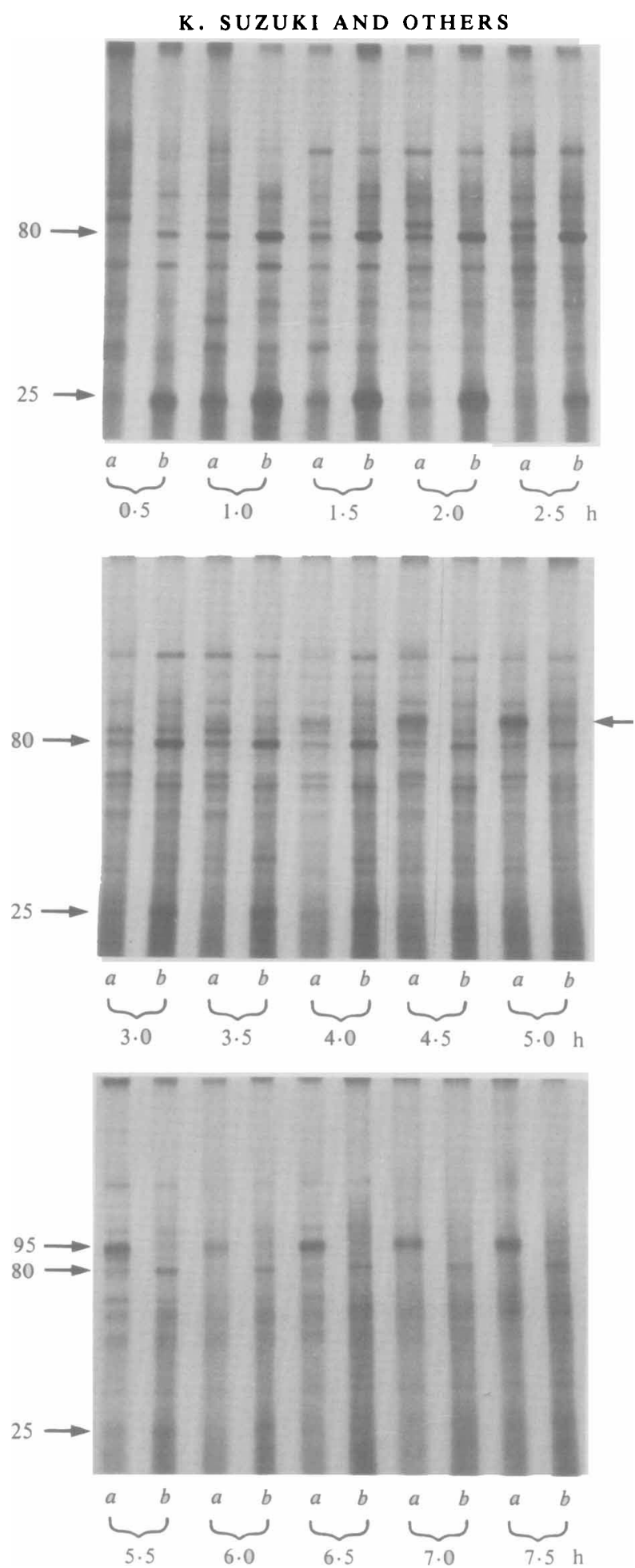

Fig. 2. Fluorograms after SDS-PAGE of polypeptides synthesized by spores pulse-labelled with $\left[{ }^{3} \mathrm{H}\right.$ |leucine for each $30 \mathrm{~min}$ period until $7.5 \mathrm{~h}$ after the start of incubation at $24{ }^{\circ} \mathrm{C}(a)$ or $32{ }^{\circ} \mathrm{C}(b)$. The radioactivity of each sample was adjusted to 10000 c.p.m. The numbers indicate the molecular masses of the polypeptides in kilodaltons. 


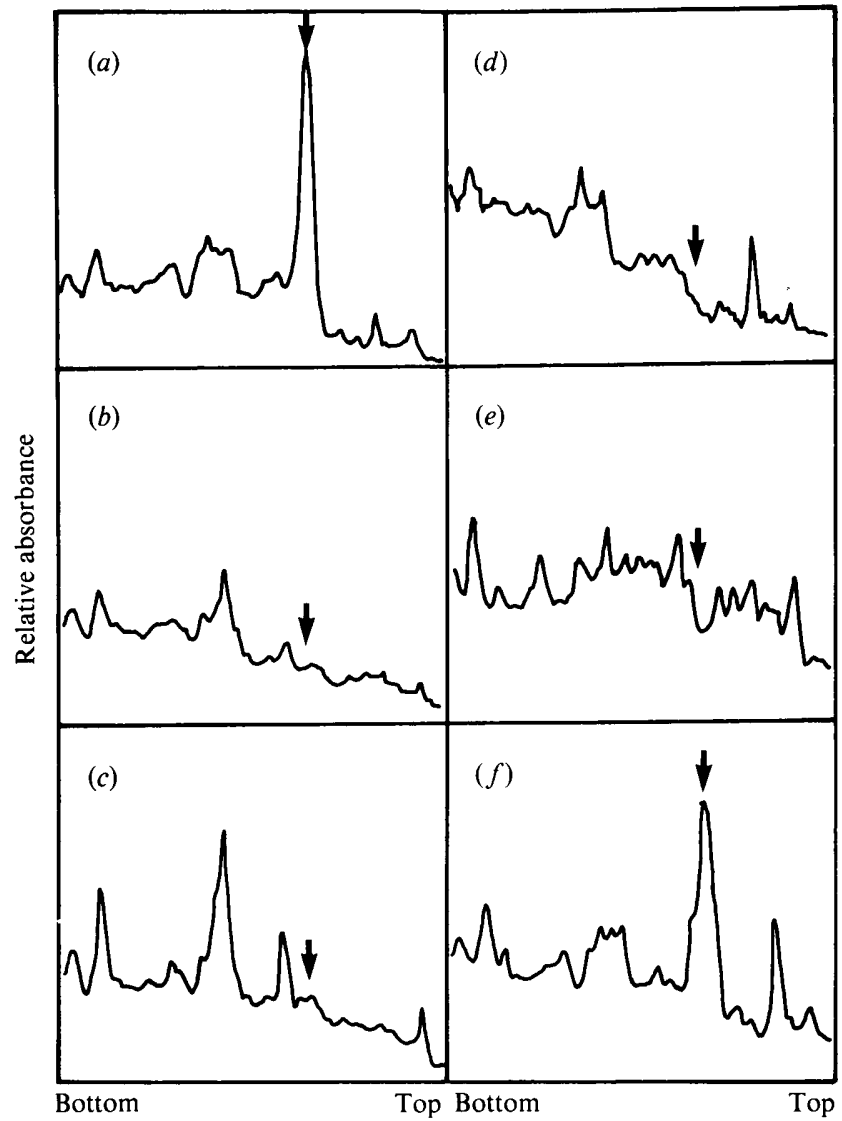

Fig. 3. Scanning patterns of fluorograms after SDS-PAGE of polypeptides synthesized by spores incubated under various conditions and pulse-labelled with $\left[{ }^{3} \mathrm{H}\right]$ leucine for $1 \mathrm{~h}$, starting $6 \mathrm{~h}$ after the start of incubation. The arrows indicate the location of the $95 \mathrm{~K}$ polypeptide. The radioactivity of each sample was adjusted to 10000 c.p.m. Incubation conditions: (a) $24{ }^{\circ} \mathrm{C} ;(b) 32{ }^{\circ} \mathrm{C} ;(c) 24{ }^{\circ} \mathrm{C}$ for $4 \mathrm{~h}$ followed by $32^{\circ} \mathrm{C} ;(d) 24^{\circ} \mathrm{C}$ in the presence of $0.5 \mathrm{M}$-sucrose; $(e) 32{ }^{\circ} \mathrm{C}$ for $6 \mathrm{~h}$ followed by $24^{\circ} \mathrm{C} ;(f)$ $32{ }^{\circ} \mathrm{C}$ for $4 \mathrm{~h}$ followed by $24^{\circ} \mathrm{C}$.

The fluorograms of polypeptides in the three fractions are shown in Fig. $1(b, c, d)$. The $72 \mathrm{~K}$, $43 \mathrm{~K}$ and $38 \mathrm{~K}$ polypeptides were found to be specifically synthesized in the $20000 \mathrm{~g}$ supernatant fraction only during the $5-25 \mathrm{~min}$ pulse period. The $155 \mathrm{~K}, 93 \mathrm{~K}$ and $60 \mathrm{~K}$ polypeptides, however, appeared common to the $20000 \mathrm{~g}$ supernatant fraction for the three pulse periods. The $76 \mathrm{~K}$ polypeptide was detected only in the $1000 \mathrm{~g}$ pellet fraction for the 5-25 min and 60-80 min pulse periods. Polypeptides which appeared in the $20000 \mathrm{~g}$ pellet fraction were detected in the other two fractions for all pulse periods.

To investigate the synthesis of polypeptides involved in appressorium formation, spores were incubated at $24{ }^{\circ} \mathrm{C}$ (appressoria formed) and at $32^{\circ} \mathrm{C}$ (appressoria not formed) and pulse-labelled with $\left[{ }^{3} \mathrm{H}\right]$ leucine $\left(5 \mu \mathrm{Ci} \mathrm{m}{ }^{-1}\right)$ for each $30 \mathrm{~min}$ period from the start of incubation. Synthesized proteins were analysed by SDS-PAGE and fluorography (Fig. 2). In the early stage, from 0 to $3.5 \mathrm{~h}$ incubation, no specific polypeptide was synthesized in spores incubated at $24^{\circ} \mathrm{C}$. However, in the later stages after $3.5 \mathrm{~h}$, a $95 \mathrm{~K}$ polypeptide was newly synthesized specifically in spores incubated at $24^{\circ} \mathrm{C}$. This polypeptide was the most radioactive of those detected from the $24{ }^{\circ} \mathrm{C}$ incubation. Synthesis of this polypeptide preceded the initiation of appressorium formation by $1 \mathrm{~h}$ and continued during appressorium formation. At $32{ }^{\circ} \mathrm{C}$, the $80 \mathrm{~K}$ and $25 \mathrm{~K}$ polypeptides were more radioactive than those at $24{ }^{\circ} \mathrm{C}$ from the start of incubation. 


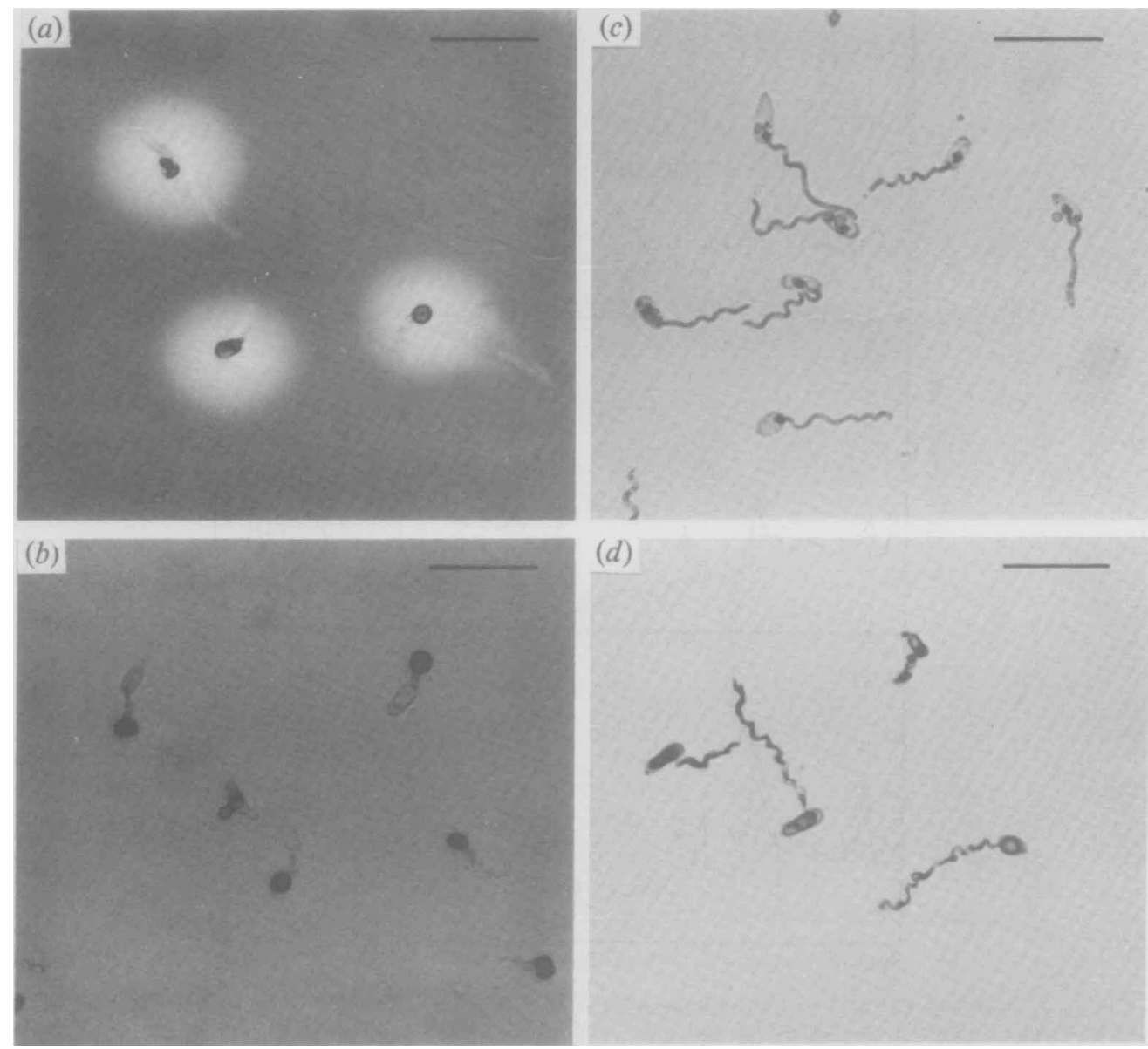

Fig. 4. Spore germination and appressorium formation on nitrocellulose membranes: $(a)$ incubated at $24^{\circ} \mathrm{C}$ for $48 \mathrm{~h} ;(b)$ incubated at $24^{\circ} \mathrm{C}$ in the presence of $3.55 \mu \mathrm{M}$-cycloheximide for $32 \mathrm{~h}$, starting $1 \mathrm{~h}$ after the start of incubation, followed by incubation in water for a further $48 \mathrm{~h}$; (c) incubated at $32^{\circ} \mathrm{C}$ for $48 \mathrm{~h} ;(d)$ incubated at $24{ }^{\circ} \mathrm{C}$ in the presence of $0.5 \mathrm{M}$-sucrose for $48 \mathrm{~h}$. After incubation the membranes were stained with $\mathrm{ZnCl}_{2} / \mathrm{KI}$ solution $(a, b)$ or lactophenol cotton blue $(c, d)$. The bar markers represent $30 \mu \mathrm{m}$.

The association of the $95 \mathrm{~K}$ polypeptide with appressorium formation was then investigated. Spores of $C$. lagenarium did not form appressoria if (1) they were incubated at $32{ }^{\circ} \mathrm{C}$ from the start of incubation, (2) they were pretreated at $32^{\circ} \mathrm{C}$ for more than $6 \mathrm{~h}$ before incubation at $24^{\circ} \mathrm{C}$, (3) they were incubated at $24^{\circ} \mathrm{C}$ for the first $4 \mathrm{~h}$, then subsequently at $32{ }^{\circ} \mathrm{C}$, or (4) they were treated with $0.5 \mathrm{M}$-sucrose at $24{ }^{\circ} \mathrm{C}$ from the start of incubation (spore germination was not influenced at this concentration of sucrose - see Fig. $4 d$ ). Spores were incubated under one of these conditions and pulse-labelled with $\left[{ }^{3} \mathrm{H}\right]$ leucine for $1 \mathrm{~h}$, starting $6 \mathrm{~h}$ after the start of incubation. The scanning patterns of fluorograms of polypeptides synthesized under the various conditions that suppressed appressorium formation are shown in Fig. $3(b-e)$ : the $95 \mathrm{~K}$ polypeptide was not detected under these conditions. On the other hand, when spores were incubated at $32^{\circ} \mathrm{C}$ for $4 \mathrm{~h}$ after the start of incubation and then transferred to $24^{\circ} \mathrm{C}$, they could form appressoria and the $95 \mathrm{~K}$ polypeptide was present (Fig. $3 f$ ). These results suggest that the $95 \mathrm{~K}$ polypeptide is closely related to appressorium formation. 
Table 1. Relation between appressorium formation in the presence of cycloheximide and the ability of spore germlings to penetrate nitrocellulose membranes

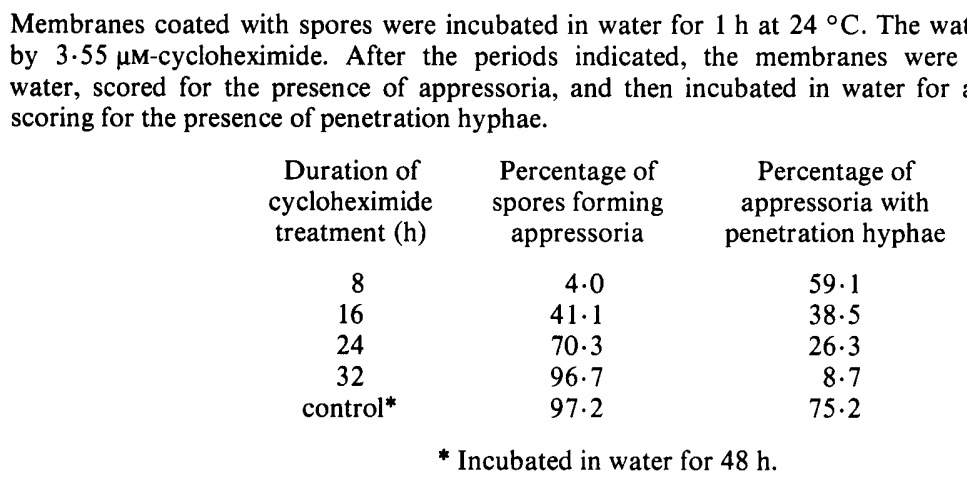

As reported previously (Tani et al., 1977), similar appressoria were formed both when protein synthesis from the first $1 \mathrm{~h}$ after incubation was inhibited by cycloheximide and when it was not (Fig. $4 a, b$ ). (In the presence of cycloheximide, spore germination and appressorium formation were, however, delayed relative to the control incubations.) The ability of appressoria formed with and without cycloheximide treatment to penetrate nitrocellulose membranes was compared. The membranes around the penetration sites did not stain with $\mathrm{ZnCl}_{2} / \mathrm{KI}$ solution, so forming clear haloes around the appressoria. Hyphae growing in the membranes were readily observed in the control incubations (Fig. $4 a$ ). When spores were treated with cycloheximide for $32 \mathrm{~h}$ after the initial $1 \mathrm{~h}$ incubation (i.e. until the appressoria had matured), haloes were rarely observed around the appressoria, even after the removal of cycloheximide and a further $48 \mathrm{~h}$ incubation in water (Table 1; Fig. $4 \mathrm{~b}$ ). However, if cycloheximide was removed after only 8 or $16 \mathrm{~h}$, before the appressoria had matured, penetration hyphae from the appressoria were observed after incubation in water for a further $48 \mathrm{~h}$ (Table 1). At $32{ }^{\circ} \mathrm{C}$ or in the presence of $0.5 \mathrm{M}$-sucrose, the spore germ tubes could elongate but they did not form appressoria and did not penetrate the nitrocellulose membranes (Fig. $4 c, d$ ).

\section{DISCUSSION}

Quantitative and qualitative differences in proteins synthesized during spore germination have been found in experiments both in vivo and in vitro (Van Etten et al., 1972; Wenzler \& Brambl, 1978), but the significance of these proteins has not been sufficiently discussed. Our previous work revealed that protein synthesis during the first $40 \mathrm{~min}$ was essential for the germination of $C$. lagenarium spores and suggested that this protein synthesis was qualitatively and quantitatively different from that of the subsequent incubation period (Furusawa et al., 1977). In the present study, three different pulse-labelling periods were used: 5-25 min (non-germinated, protein synthesis essential for spore germination), 60-80 min (non-germinated, protein synthesis not necessary for spore germination) and 160-180 min (initiation of germ tube emergence, protein synthesis not necessary for spore germination). Of the polypeptides detected in the pulse-labelled preparations, the $72 \mathrm{~K}, 43 \mathrm{~K}$ and $38 \mathrm{~K}$ polypeptides specific to the 5-25 min pulse period are the most likely candidates for polypeptides essential for spore germination, because spores could germinate even if protein synthesis after 40 min incubation was completely inhibited by cycloheximide.

Although protein synthesis in the early stage of incubation $(0-40 \mathrm{~min})$ is indispensable for the initiation of spore germination, our results suggest that morphogenesis of the appressorium does not require de novo protein synthesis after $40 \mathrm{~min}$ incubation. However, 
the appearance of the $95 \mathrm{~K}$ polypeptide was closely related to appressorium formation. It is suggested that this polypeptide might be closely connected with the function of appressoria, because appressoria formed in the presence of cycloheximide seemed to have little ability to penetrate artificial membranes. Perhaps the mechanisms involved in the morphogenesis and the function of appressoria are separated at the level of protein synthesis in $C$. lagenarium. Proteins necessary for the morphogenesis of appressoria probably already exist in dormant spores. Protein synthesis necessary for the capacity to penetrate, however, might occur during the morphogenesis of appressoria but not after their structural maturation.

From studies with inhibitors of protein synthesis, Miehle \& Lukezic (1972) suggested that protein synthesis was required for spore germination and appressorium formation of $C$. trifolii. In addition, Staples et al. (1976) have investigated the relation between appressorium formation and nuclear division during spore germination of $C$. truncatum and showed that blocking of nuclear division inhibited appressorium formation. They have also reported that cycloheximide inhibited both appressorium formation and nuclear division. In our preliminary experiments, we found both spore germination and appressorium formation were completely inhibited if cycloheximide at a concentration higher than $35.5 \mu \mathrm{M}$ was added to the spore suspension at any stage of germination. This suggests that high concentrations of cycloheximide not only inhibit protein synthesis but also affect other metabolic processes. The concentration of cycloheximide used in our experiments on appressorium formation $(3.55 \mu \mathrm{M})$ was the minimum sufficient to suppress only protein synthesis in spores; no protein band was detected on fluorograms with this concentration. It is clearly important to use a dose of cycloheximide which inhibits only protein synthesis in spores if the necessity of protein synthesis for morphological differentiation of spores is to be correctly evaluated.

The authors wish to acknowledge the helpful advice of Dr H. Kunoh, Mie University.

\section{REFERENCES}

Araki, F. \& MiYagi, Y. (1976). Effect of isoprothiolane on the infection process of Pyricularia oryzae. Annals of the Phytopathological Society of Japan 42, 401-406.

BonNer, W. M. \& LASKey, R. A. (1974). A film detection method for tritium-labelled proteins and nucleic acids in polyacrylamide gels. European Journal of Biochemistry 46, 83-88.

Dunkle, L. D., Maheshwari, R. \& Allen, P. J. (1969). Infection structures from bean rust uredospores: effect of RNA and protein synthesis inhibitors. Science 163, 481-482.

Emmett, R. W. \& PARbery, D. G. (1975). Appressoria. Annual Review of Phytopathology 13, $147-167$.

Furusawa, I., Nishiguchi, M., Tani, M. \& Ishida, N. (1977). Evidence of early protein synthesis essential to the spore germination of Colletotrichum lagenarium. Journal of General Microbiology 101 , 307-310.

ISHIDA, N. \& AKAI, S. (1969). Relation of temperature to germination of conidia and appressorium formation in Colletotrichum lagenarium. Mycologia 61, 382-386.

LAEMMLI, U. K. (1970). Cleavage of structural proteins during the assembly of the head of bacteriophage T4. Nature, London 227, 680-685.

LASKey, R. A. \& Mills, A. D. (1975). Quantitative film detection of ${ }^{3} \mathrm{H}$ and ${ }^{14} \mathrm{C}$ in polyacrylamide gels by fluorography. European Journal of Biochemistry 56. 335-341.

LOVETT, J. S. (1976). Regulation of protein metabolism during fungal spore germination. In The Fungal Spore, pp. 189-242. Edited by D. J. Weber \& W. H. Hess. New York: John Wiley.

Miehle, B. R. \& Lukezic, F. L. (1972). Studies on conidial germination and appressorium formation by Colletotrichum trifolii Bain \& Essary. Canadian Journal of Microbiology 18, 1263-1269.

RAMAKRISHNAN, L. \& STAPLES, R. C. (1970). Changes in ribonucleic acids during uredospore differentiation. Phytopathology 60, 1087-1091.

Silverman, P. M., Huh, M. M. \& Sun, L. (1974). Protein synthesis during zoospore germination in the aquatic phycomycete Blastocladiella emersonii. Developmental Biology 40, 59-70.

Staples, R. C. \& Yaniv, Z. (1976). Protein and nucleic acid metabolism during germination. In Encyclopedia of Plant Physiology New Series 4, Phvsiological Plant Pathology, pp. 86-103. Edited by R. Heitefuss \& P. H. Williams. Berlin: SpringerVerlag.

Staples, R. C., Laccetti, L. \& Yaniv, Z. (1976). Appressorium formation and nuclear division in Colletotrichum truncatum. Archives of Microbiology 109. $75-84$. 
StUdier, F. W. (1973). Analysis of bacteriophage T7 early RNAs and proteins on slab gels. Journal of Molecular Biology 79, 237-248.

Tani, M., Ishida, N. \& Furusawa, I. (1977). Effect of temperature and antibiotics on appressorium formation in spores of Colletotrichum lagenarium. Canadian Journal of Microbiology 23, 626-629.

Van EtTen, J. L., Roker, H. R. \& Davies, E. (1972). Protein synthesis during fungal spore germination: differential protein synthesis during germination of Botryodiplodia theobromae spores. Journal of Bacteriology 112, 1029-1031.

WENZLER, H. \& BRAMBL, R. (1978). In vitro translation of polyadenylate-containing RNAs from dormant and germinating spores of the fungus Botryodiplodia theobromae. Journal of Bacteriology 135, $1-9$. 